\title{
The Future of Ethics in Medicine
}

\author{
Malika Raza, ${ }^{1}$ Hasnain Abbas Dharamshi, ${ }^{1,}$ Syed Zohaib Ahsan, ${ }^{2}$ Zehra Naqvi, ${ }^{2}$ Tahira Naqvi, ${ }^{1}$ Ali Abbas \\ Mohsin Ali, ${ }^{2}$ and Jamaluddin Malik Abbas ${ }^{3}$ \\ ${ }^{1}$ Karachi Medical and Dental College, Karachi, Pakistan \\ ${ }^{2}$ Sindh Medical College, Karachi, Pakistan \\ ${ }^{3}$ Jinnah Medical and Dental College, Karachi, Pakistan \\ "Corresponding author: Hasnain Abbas Dharamshi, Karachi Medical and Dental College, Karachi, Pakistan. Tel: +92-3312729129, E-mail: dr.hasnain.dh@hotmail.com
}

Received 2015 January 28; Accepted 2015 January 28.

Keywords: Ethics, Fertilization, Reproduction

\section{Introduction}

All around the world, physicians and surgeons are highly valued and respected. For a good physician, acquiring knowledge and following medical ethics is equally important. The latest advances in medical technology, however, are raising many questions relative to ethics. From the time of Hippocrates through today, many steps have been taken to keep the gap between ethics and medicine at a minimum. On the one hand, this evolution in medicine has made management and treatment of many problems easy, but on the other hand, it has also caused serious disputes in some regions of the world. Use of stem cell cloning, elective abortions, etc. are considered unethical on one side of world, in contrast to other parts. For instance, reproductive cloning has also caused an increase in certain crimes, and in-vitro fertilization has allowed many parents the blessing of children but this technique is under question in Islamic states. Organ grafting and donating is a lifesaving process and easily adopted in some countries, but in other lands it is considered a violation of cultural and religious norms and values.

\section{Arguments}

A man nearly always advances towards God in giving health to him. Physicians work day and night to improve the health status of the country and the world. For needy patients it is important that physicians know and epitomize the values of medicine, especially empathy, autonomy and expertise, along with reverence of primary human rights. These things form the basis of medical ethics. The importance of medical ethics is well-stressed by Potter Stewart, who said that "Ethics is knowing the difference between what you have a right to do and what is right to do."

Revolutionary inventions and advancements in the field of medicine have sometimes meant that traditional medical ethics could not be followed. The world medical association (WMA) has chosen over the years to update the Hippocratic oath, resulting in the creation of the declaration of Geneva; after this an international code for medical ethics was composed. Finally, these two documents were combined into and adopted as the declaration of Helsinki. Despite all these steps, new medical techniques have raised questions regarding medical ethics among different societies, and most of the positive efforts to promote medical ethics have been destroyed.

The possibility of human cloning, the use of fetal tissues in the treatment of diseases, legalized abortion in some countries, and the legalization of physician-assisted suicide in some parts of the world, as well as the immense increase in the cost of various therapeutic maneuvers by pharmaceuticals and other money managers, have placed significant moral and ethical pressure on physicians (1), because physicians are being seen as caring only about the money.

Various forms of research in the field of cloning and stem cell research have introduced new hopes for the treatment of serious diseases. Although reproductive cloning has had significant consequences, pre- and postembryonic cell research for therapeutic purposes is valuable so long as there is a genuine and justifiable reason and it is performed with full consideration and all necessary precautions (2). Another example of a technology which raises ethical issues is assisted reproductive technology (ART). Even as in-vitro fertilization, a part of this new technology, has helped many childless couples, ART has provoked many ethical, legal, and social disputes. ART is a medium to challenge and evaluate the way in which mankind, social justice, equality, and claims to genomic offspring are viewed (3).

The development of pluripotent stem cells (PSCs) has also caught the attention of scientists, politicians, and

Copyright ( ) 2016, Iranian Red Crescent Medical Journal. This is an open-access article distributed under the terms of the Creative Commons Attribution-NonCommercial 4.0 International License (http://creativecommons.org/licenses/by-nc/4.0/) which permits copy and redistribute the material just in noncommercial usages, provided the original work is properly cited. 
devotees of ethical ideals. Embryonic stem cell transfer is awash in ethical concerns, particularly regarding personhood, human solemnity, and justice towards humanity that arise when dealing with the embryo, which is life in its most primitive form. Embryonic stem cell research forces us to choose between two moralities: the obligation to prevent suffering and the duty to respect human life. In the rationale of embryonic stem cell research, it is impossible to respect both principles. It is a controversial national and international issue, and many influential bodies have placed restrictions on what may be done with embryos and regarding embryonic cell transfer. Associated ethical issues surrounding such procedures include getting informed consent from and the safety risks for the women who donate the eggs necessary for the creation of embryos by in vitro fertilization (4). In addition, in order to acquire embryonic cells, the primitive embryo has to be irretrievably damaged. This means destroying a potential human being. However, embryonic stem cell research could lead to the development of new medical remedies that would ease the suffering of many people. So which principle should dominate in this situation? The answer depends upon how we regard the embryo. Does it qualify for the status of a person? In the United States, the question of when human life begins has been highly controversial and closely linked to debates over abortion. It is not disputed that embryos have the potential to become human beings; if inserted into a woman's uterus at the appropriate hormonal phase, an embryo could implant, develop into a fetus, and become a live-born child. Some people in the United States, as a matter of religious reliance and moral faith, believe that "life originates at conception" and that an embryo is consequently a person. From this standpoint, an embryo has rights that must be respected, and procuring a blastocyst and confiscating the inner mass to take an embryonic stem cell line is effectively the same as committing murder (5).

The first successful kidney transplant was carried out between monozygotic identical twins in Boston in 1954. A decade later, liver transplants were conducted to treat patients with end stage liver diseases. These organs can be taken either from dead or living donors. Cadaveric transplant is complex because of the difficulties with gaining access to the organs after someone has died. Usually, the donor is a youth, healthy and hearty person who was injured or killed violently, and then a kidney or a liver is removed from a person whose brain is dead but whose heart is still working. This scenario raises several ethical as well as religious issues, including gaining consent and the various methods of determining brain-death in different groups of people. This belief of brain death is now acknowledged by the majority of people. However, this view is not universally accepted. For example, orthodox Jews believe that death occurs due to the heart malfunctioning rather than the brain, and throughout most parts of Asia brain death is not yet recognized as a phenomenon. In addition, the kidney will only remain transplantable for up to one hour after the heart stops beating, and the ethical issue then lies in seeking the family member's consent in this brief period of time. Because of the restricted number of cadaveric organs, in all countries a directory with a very long waiting list has been the foremost means of assigning priority to patients awaiting transplant. Living donation breaches the Hippocratic oath to "first, do no harm" However, informed consent, the absence of oppression, and a careful effort to minimize the prospective risks can alleviate this deviation from the oath. To expand the donor population, new categories of donors have recently been suggested. These groups include sensitively related donors, children, and prisoners. As the scarcity of organs remains an issue, the criteria used for organ donation are questionable. All needy patients are placed on a waiting list, and the basic predicament is determining which patient should be given the highest priority (6)

\section{Conclusion}

To overcome these negative perspectives of medicine, bioethics has evolved, which allows for an appropriate formal vigilance of the medical profession and to ensure powerful communication between ethics and medicine (7).

\section{Acknowledgments}

Ahmad Faraz.

\section{References}

1. Kamal RS. Ethics in medical practices. R S kamal. Review article. JPMA. 2004;54(6):325-7.

2. Al-Aqeel AI. Human cloning, stem cell research. An Islamic perspective. Saudi Med J. 2009;30(12):1507-14. [PubMed:19936411].

3. Brezina PR, Zhao Y. The ethical, legal, and social issues impacted by modern assisted reproductive technologies. Obstet Gynecol Int. 2012;2012:686253. doi: 10.1155/2012/686253. [PubMed: 22272208].

4. Brind'Amour K. Ethics and Induced Pluripotent Stem Cells. United State: Embryo Project; 2009.

5. Lo B, Parham L. Ethical issues in stem cell research. Endocr Rev 2009;30(3):204-13. doi:10.1210/er.2008-0031. [PubMed: 19366754].

6. Taher LS. Moral and ethical issues in liver and kidney transplantation Saudi J Kidney Dis Transpl. 2005;16(3):375-82. [PubMed: 17642808].

7. Benaroyo L. [Can we accept medical progress without progress in ethics?]. J Int Bioethique. 2013;24(2-3):23-42. [PubMed: 23991542] 163-4. 